\title{
Technology Information as an Opportunity to Build a Business
}

\author{
F A Prasetio ${ }^{1 *}$, and I D Sumitra ${ }^{2}$ \\ \{ adi.prasetio366@mahasiswa.unikom.ac.id $^{1}, \underline{\text { irfan.dwiguna@email.unikom.ac.id }}^{2}$ \}
}

Department of Information System, Universitas Komputer Indonesia, Indonesia ${ }^{1}$, Master of Information System Department, Universitas Komputer Indonesia, Indonesia ${ }^{2}$

\begin{abstract}
The purpose of this study is to find out what opportunities can be used to do business using information technology and also to find out how to take advantage of these opportunities so that we can do business using current technology and information. The subject of this research is entrepreneurs who are still not familiar with the technology and information used today; the research method used to compile this scientific work is descriptive research methods. The results of this study are to find out whether current business people have used technology and information to develop their business. This study discusses what entrepreneurs and information technology can be used to build their business. It can be concluded that using technology and information will have a large business opportunity. Therefore, we are required to use business opportunities that are available so that we can compete in business using technology and information media as intermediaries for competing in business.
\end{abstract}

Keywords: technology information, online business, buyer

\section{Introduction}

Computers contribute to current performance; most people who are asked to identify the power of computer computers now tend to do computational tasks such as being able to calculate large numbers [1]. The business has always been an active agent of progress, through innovation and new products, by encouraging technological equity, or reducing costs by increasing productivity activities, improving services and improving quality, and thus making something good in life affordable for more people [2]. Technology can be used to develop new product concepts and to assess the competitiveness of existing product concepts. Analyzed information is used for strategic decisions in the future and also for budget allocation.

Furthermore, the source of knowledge can be facilitated by scouts. In an environment with high technological complexity and the need for volatile markets, external technology sources are becoming increasingly important to ensure the competitiveness of companies [3]. The novelty of business opportunities and subsequent innovations may be very different from companies. Some companies can introduce new products and services to the world, while others can introduce improvements from existing ones, or similar products at lower prices. The novelty of business opportunities is closely related to the novelty of the founders of the knowledge base [4].

The design of business processes and IT has mutually needed relationships; their relationships are never fully exploited in practice. The authors define this relationship as a 
recursive pattern. On the one hand, it is naturally expected that the choice of certain ways of doing business in an organization will influence the design and structure of the IS to support this process. On the other hand, IT progress can generate opportunities to create new organizations and therefore influence the layout of specific business processes [5]. Some studies take into account the marketing and marketing aspects of social media opportunities in customer interaction, but the majority are found to be fully concentrated on the one-to-customer aspect of corporate marketing, not more approaches to interaction. However, there are no studies found in social media opportunities in general in customer interaction, and especially not from an innovation perspective [6]. E-commerce website planning refers to the overall planning of the construction and operation of a website from a strategic height. The main content should include the objectives of website construction and business analysis, site-targeted customer analysis, analysis of the website's market position, technical and economic feasibility analysis, selecting the operational environment and equipment and so on. The purpose of website construction and business analysis. [7].Web sites are widely used commercially. As the use and dependence on Web technology increases, so does the need to assess the factors associated with the success of a Web site. The aim is to explore these factors in the context of electronic commerce [8]. Internet use in business can change as a tool that serves to electronically transact information into a tool for business strategy applications, such as marketing, sales and customer service. Marketing on the Internet tends to penetrate various obstacles, national boundaries, and without standard rules. While conventional marketing, goods flow in large parties, through seaports, using containers. [9].Based on the value of the IT business research, it presents an electronic business value framework that mentions the relationship between performance (eg, Internet applications, processes, and electronic business readiness of customers and suppliers), and operational excellence and financial metrics. We believe that companies involved in the transformation of electronic businesses must make investments synergistic and committed resources not only in information technology but also must align processes and customers and supplier readiness to maximize benefits. The general model and approach provide a foundation for managers to analyze the types of electronic business initiatives that lead to better operational and financial performance. Furthermore, management can use this model to measure electronic business projects and to identify areas that may require additional attention and resources [10]. Electronic business is a land of extensive business growth because it presents a fast sales method, an efficient price, always open all the time. Stores arranged on the site are a different start on sites that are considered simple [11] and can make benefit [12].

The purpose of this research is to find out how technology can relate to business and to find out whether current business people have used technology and information to develop their business. This research is referring to entrepreneurs who are still not familiar with the technology and information currently used, and this research uses descriptive research methods and serves to find out whether business people today have used technology and information to develop their business.

\section{Method}

The method used in this research is descriptive research methods because we will look for the correlation between business and technology for the future. In this study, we will find out about how technology can relate to business and find out if current business people have used utilization technology and information to develop their business. 


\section{Result and Discussion}

To find out what are the opportunities for doing business, an online business-based business website is created. In this website, sellers can sell the products they want to sell by uploading what rods to sell and provide details about the products that will be sold. sell to the buyer, for example, suppose a product on the website offers an electronic product, which appears on the web page such as, Mobile, Camera, Laptop of various brands and on the website the buyer will be offered other similar products with various brands if the buyer looking for the same product, then if the buyer wants to make a transaction. 1).

In the display of this web, provider displays products that are holding discounts. (Figure

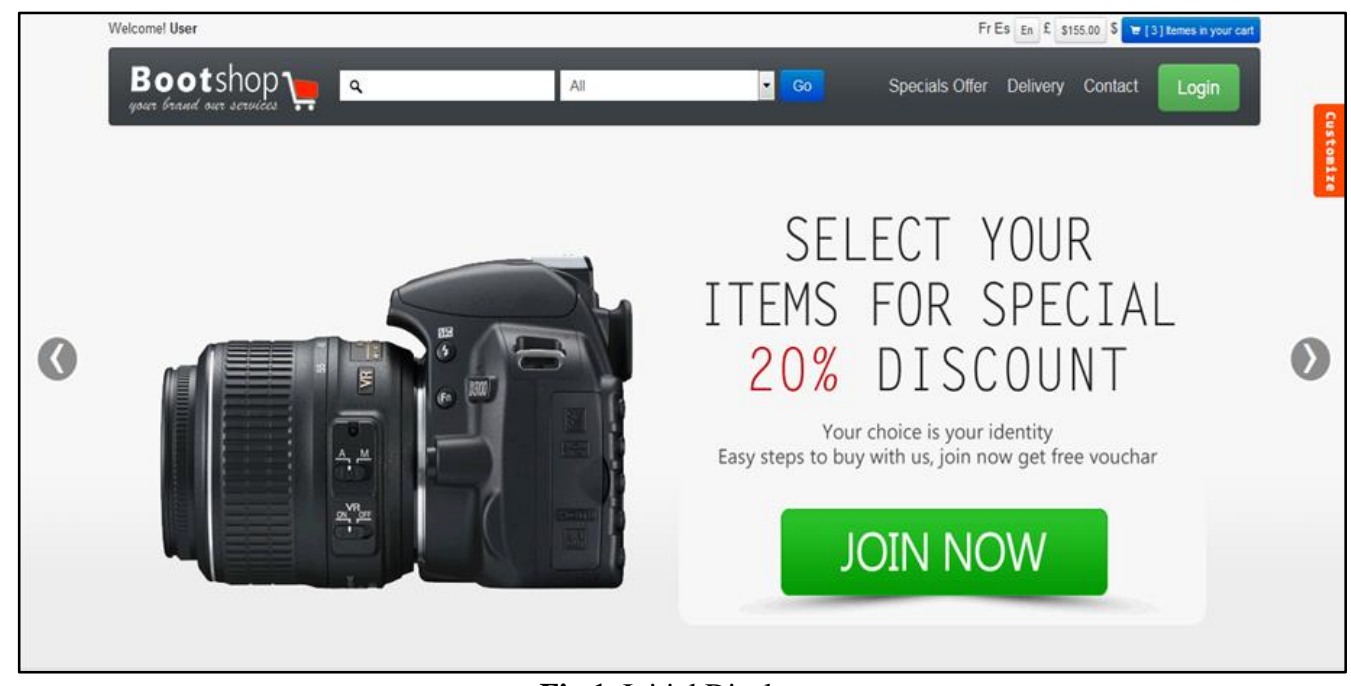

Fig 1. Initial Display.

Then also offered a payment method that offers product purchase payments indirectly using transactions from credit cards, so that buyers only have to wait for the product that we ordered sent to the buyer [13]. Buyers can order products to be purchased anywhere and anytime according to the wishes of the buyer by accessing this online-based web business through a web browser on the buyer's electronic device. (Figure 2) shows the main display. 


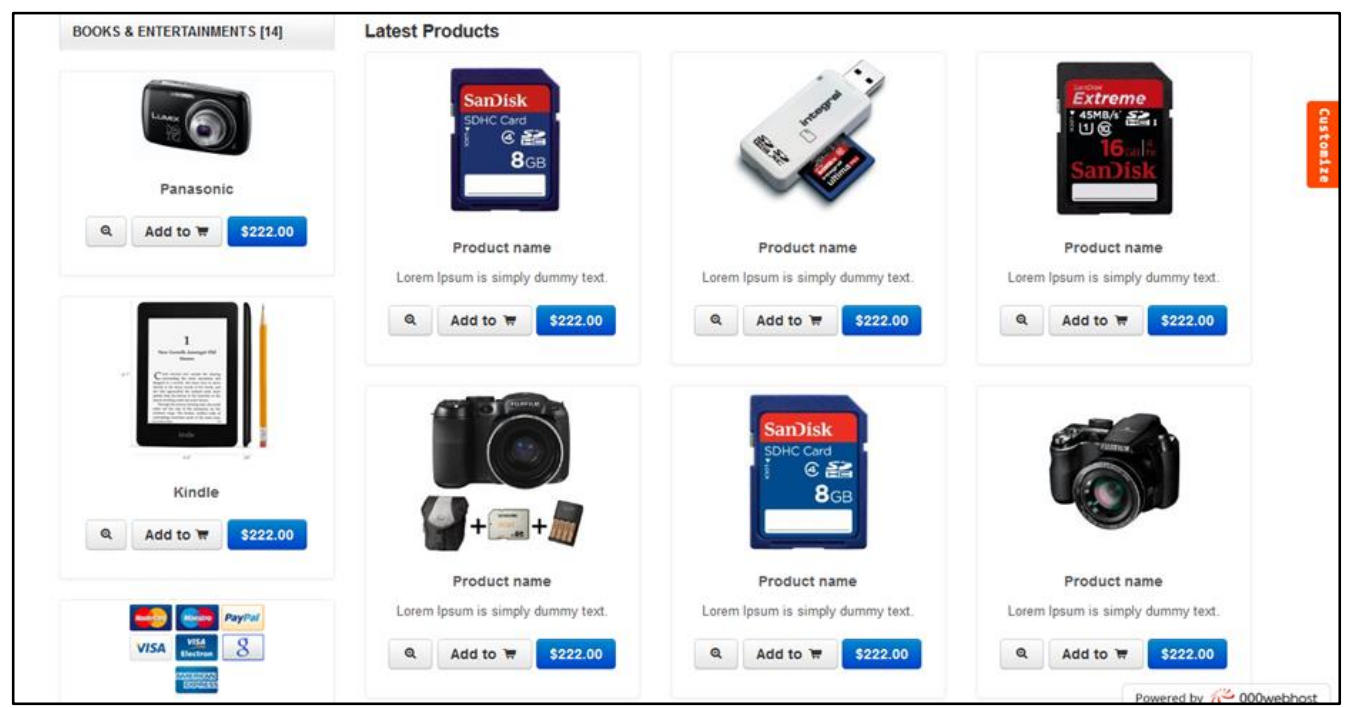

Fig 2. Main Display.

Then on the main page that is below the initial display page, has the function to make sale and purchase transactions of goods that have been provided by pressing the add button to the basket to store what products the buyer will buy using the account that was created before by the buyer. (Figure 3) shows product details.

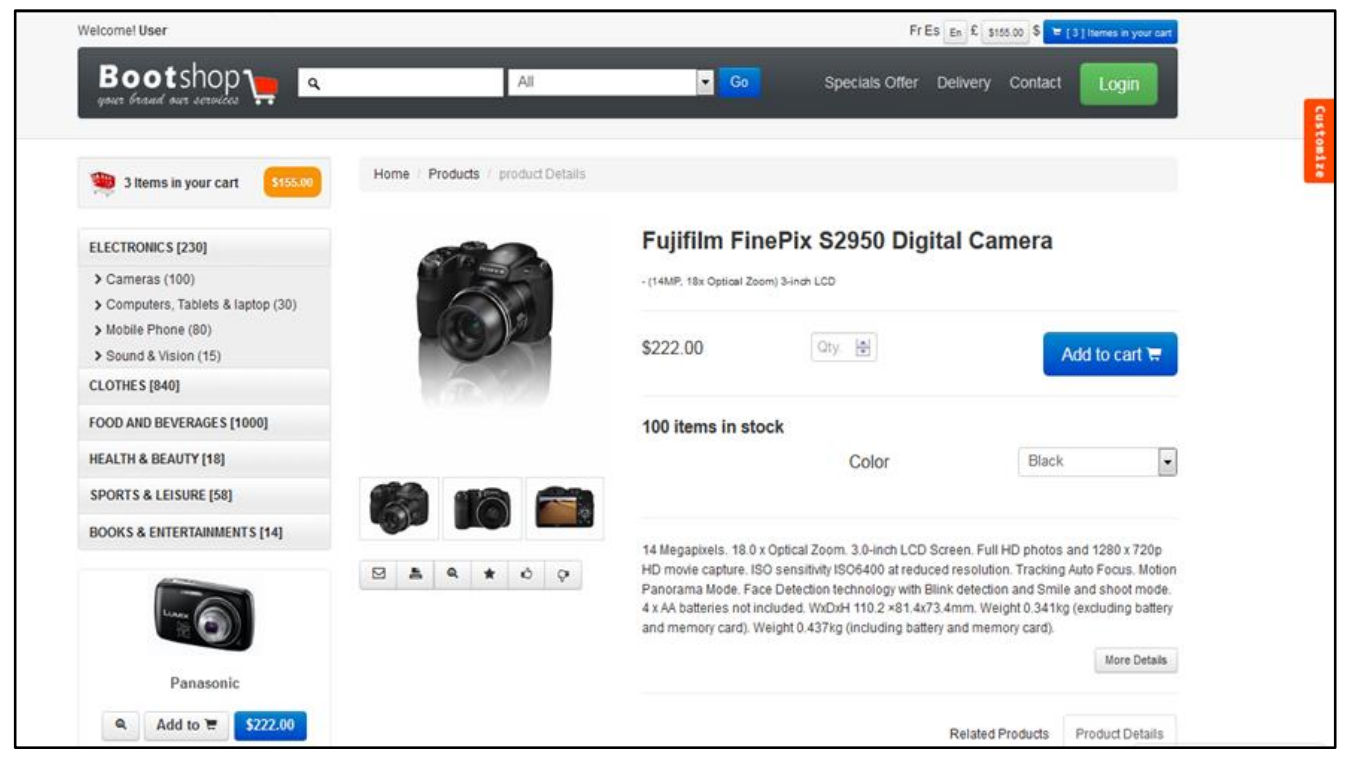

Fig 3. Product Details

After seeing and choosing the product to be purchased, there is information about the product starting from the price of the product to be purchased, product specifications, product name, and product stock. (Figure 4) shows page filling account. 


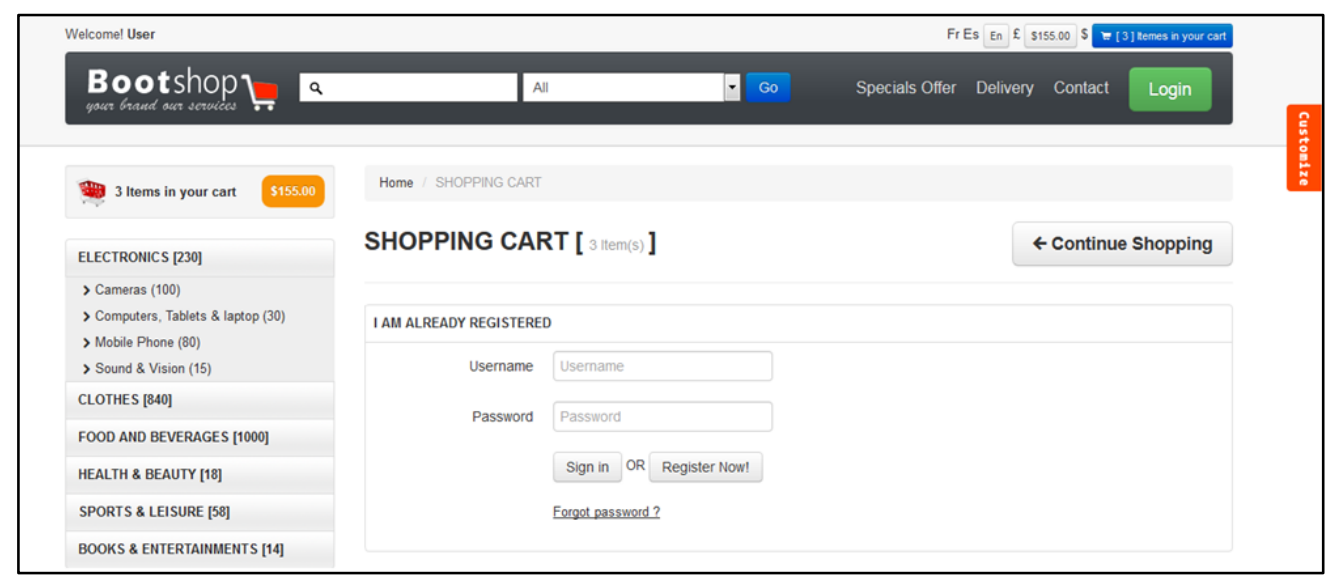

Fig 4. Page Filling Account.

On this page, if the buyer has chosen the product to be purchased, the buyer must fill out an account to make the transaction so that the product can be sent to the name and address shown to the buyer by entering an email and password that has been registered on this website. (Figure 5) shows purchase transaction pages.

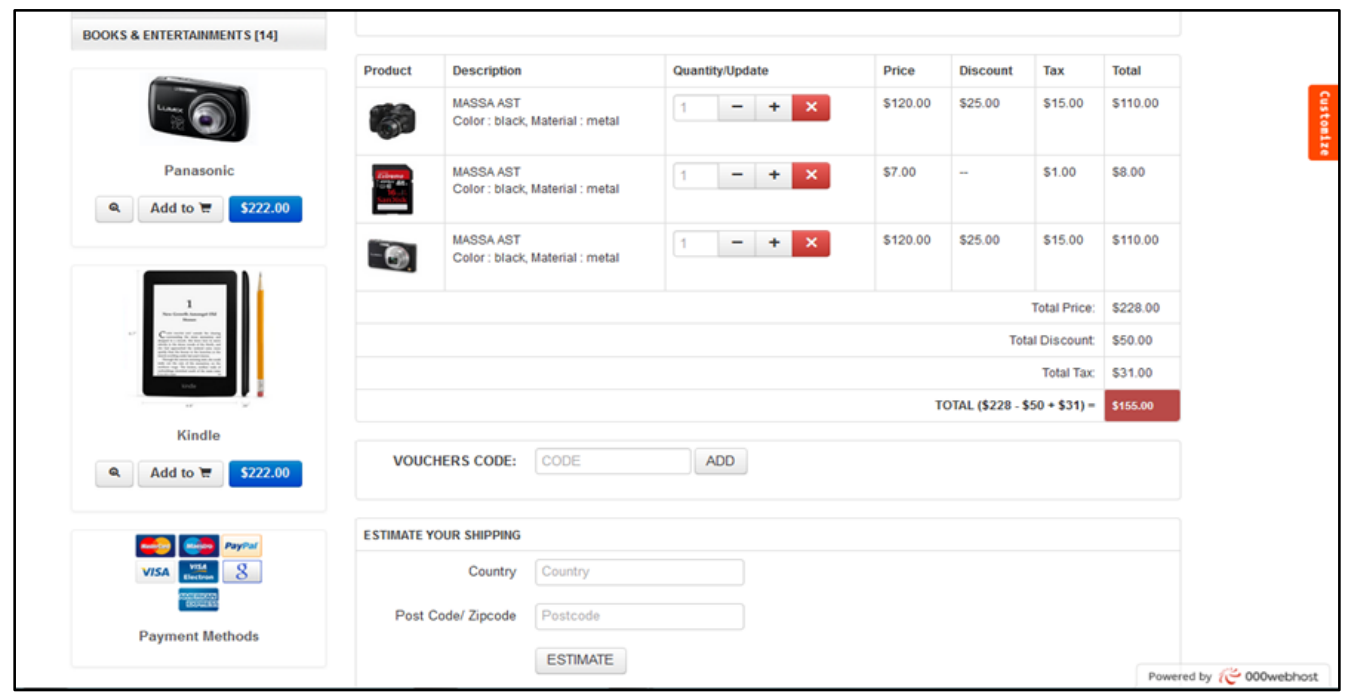

Fig 5. Purchase Transaction Pages.

On this page the buyer who has determined what products to buy, is required to process the payment of the products that the buyer will buy using the available method of purchase on this business website. (Figure 6) shows succesful purchase page. 


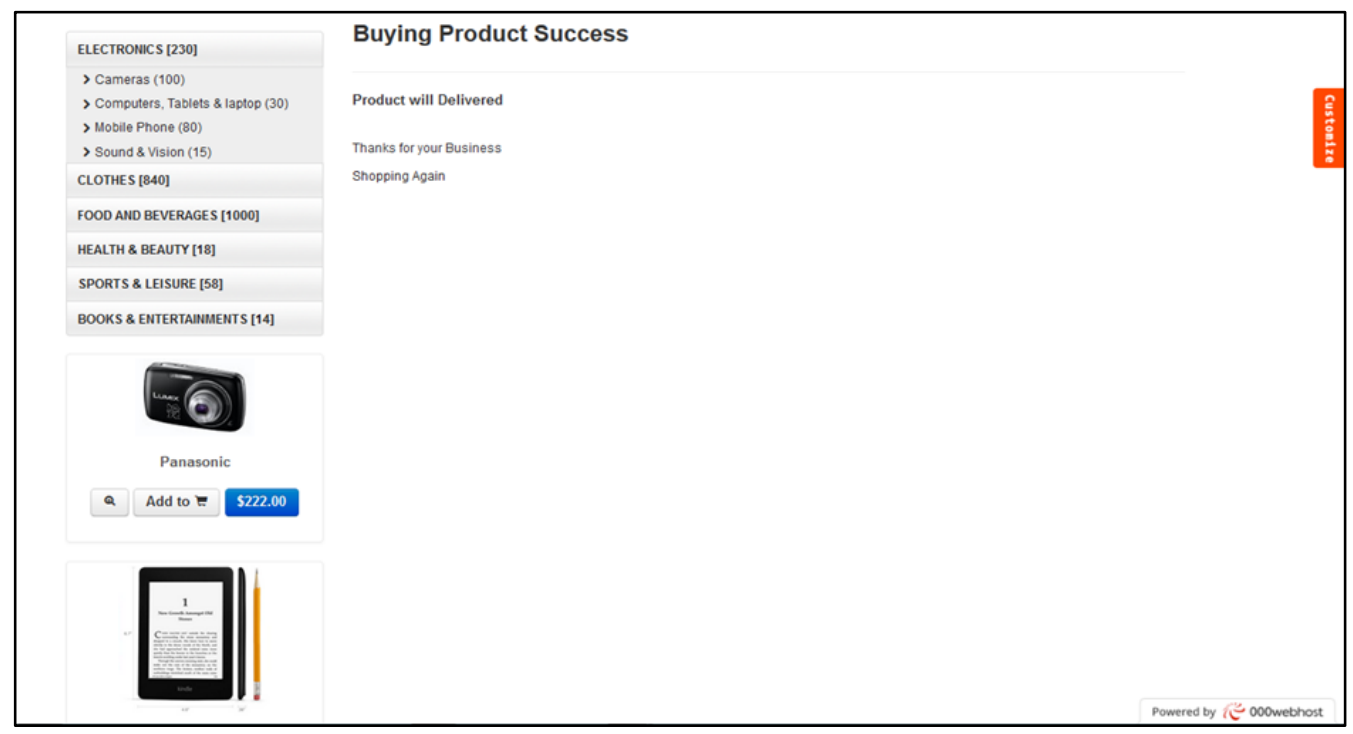

Fig 6. Successful Purchase Page.

After the buyer purchased the desired product, the buyer will be shown to the page that says the purchase transaction was successful and the buyer can continue shopping on this business web. After all transaction processes are completed, the buyer only has to wait for the item that was ordered by the buyer to the address and destination by the charging data which is filled in when transacting. Products that have been purchased cannot be returned and the money that has been used to buy the product cannot be returned. The product ordered will arrive at the destination if there is no error in filling in the purchase data. On this web, there is a problem that on this website buyers can only use credit cards to buy the items they want, while not everyone has a credit card so that the buyer will be troubled if they want to buy the desired product.

\section{Conclusion}

Business opportunities provided by technology and information nowadays are widely used by business people who initially sell by going down to the field. Lately, businessmen use internet technology to build an online business so that business people do not go down to sell their products to sell.

\section{References}

[1] Brynjolfsson, E., \& Hitt, L. M.: Beyond computation: Information technology, organizational transformation and business performance. Journal of Economic perspectives, 14(4), 23-48. (2000).

[2] Handy, C.: What is a business for?. Harvard Business Review, December. (2002).

[3] Thom, N., \& Rohrbeck, R.: Technology Foresight in the ICT Sector-Exploration of new business opportunities. In 2nd ISPIM Innovation Symposium: New York City, USA. (2009, December).

[4] Saemundsson, R., \& Dahlstrand, A. L.: How business opportunities constrain young technology-based firms from growing into medium-sized firms. Small Business Economics, 24(2), 113-129. (2005). 
[5] Bosilj-Vuksic, V., Ceric, V., \& Hlupic, V.: Criteria for the evaluation of business process simulation tools. Interdisciplinary Journal of Information, Knowledge, and Management, 2, 73-88. (2007).

[6] Jussila, J., Kärkkäinen, H., \& Leino, M.: Social media's opportunities in business-to-business customer interaction in innovation process. International Journal of Technology Marketing;. (2012).

[7] Wang, A., \& Chu, R.: Study on the Design of Electronic Commerce Website. In International Conference on Education, Management and Computing Technology (ICEMCT-15). Atlantis Press. (2015, June).

[8] Liu, C., \& Arnett, K. P.: Exploring the factors associated with Web site success in the context of electronic commerce. Information \& management, 38(1), 23-33. (2000).

[9] Yuliana, O.: Penggunaan Teknologi Internet dalam Bisnis. Jurnal Akuntansi dan Keuangan, 2(1), 3652. (2004).

[10] Barua, A., Konana, P., Whinston, A. B., \& Yin, F.: Managing e-business transformation: Opportunities and value assessment. Sloan Management Review, 43(1), 36-44. (2001).

[11] Soegoto, E, S.: Entrepreneurship Menjadi Pembisnis Ulung Edisi Revisi, Elex Media Komputindo. 339. (2010).

[12] Soegoto, E. S., \& Semesta, R. B.: Use of google AdSense for income generating activity. In IOP Conference Series: Materials Science and Engineering (Vol. 407, No. 1, p. 012065). IOP Publishing. (2018, August)

[13] Davis, V. M., Cutino, S. C., Berg, M. J., Conklin, F. S., \& Pringle, S. J. U.S.: Patent No. 6,282,522. Washington, DC: U.S. Patent and Trademark Office. (2001) 